\title{
Assessment of climate change and its environmental consequences \\ of Posidonia coastal distribution, Case Study: \\ Garawla Islands Village \\ at North west coast of Egypt \\ Dr. Ayman El-Gamal \\ and Dr. Mayada Abd El-Kader
}

Received on $2 / 10 / 2018$

Accepted on 21/11/2018 


\section{ASSESSMENT OF CLIMATE CHANGE AND ITS ENVIRONMENTAL CONSEQUENGES OF POSIDONIA COASTAL DISTRIBUTION, CASE STUDY: GARAWLA ISLANDS VILLAGE AT NORTH WEST COAST OF EGYPT

\author{
Dr. Ayman El-Gamal*1 \\ and Dr. Mayada Abd El-Kader2
}

\section{Abstract}

Seagrass wrack is considered as one of the environmental problems facing the Egyptian North West coastal zone. The wrack in the Mediterranean coast of Egypt is composed mainly from Posidonia oceanica. Its distribution is scattered at different sites along the Mediterranean beaches. The aim of this work is to study Posidonia wrack as one of the environmental problems in the Egyptian North west coast. Garawla Islands Village was selected as case study to investigate the Posidonia wrack because it considered as a serious ecological, social and economic issue. The present study assesses the environmental factors affecting its distribution and its relation with climate change and the possible way of control. The standard approach for comparing beach litter pollution has been used to assess of the beaches under investigation based on field trip data and satellite images. The average values and its standard deviation of precipitation, wind speed, relative humidity and solar intensity during 2013 were $0.24 \pm 1.64 \mathrm{~mm}, 4.41 \pm 1.34$ $\mathrm{m} / \mathrm{s}, 0.58 \pm 0.13$ fractions and $21.59 \pm 7.47 \mathrm{MJ} / \mathrm{m}^{2}$, respectively. Temporal variation of the climatic conditions with coastal plants near the study area were investigated through three years $(1997,2005$ and 2013). This indicated that the distribution of Posidonia at the coastal area is correlated with the environmental conditions. Also, the distribution of Posidonia wrack is dependent on the topography of the shoreline. The direction of dead Posidonia movements is highly affected by the climatic conditions. The study recognized the sites of accumulated Posidonia wrack. Recommendations to use special net to control this coastal problem have been suggested.

\section{Introduction}

\subsection{Seagrass and Posidonia oceanica}

Seagrasses are rhizomatous marine flowering plants. It grows in shallow, sheltered softbottomed coastal habitats CEN (2005). Posidonia oceanica is an endemic seagrass species in the Mediterranean Sea, (Dive site directory, 2006) where it covers around $50,000 \mathrm{~km}^{2}$ (Bethoux and Copin-Montegut, 1986) and around the southern coasts of Australia (PIRSA, 2003). It forms a key ecosystem component in the shallow waters (Pergent, 1992). P. oceanica is a slow growing seagrass found at depths of 5 to 35 meters. It plays an important role in oxygenating and clarifying coastal waters, provides a habitat for rich diversity of plants and animals (Kennaecodiving, 2007).

$\mathrm{P}$ oceanica is experiencing a widespread decline throughout the Mediterranean Sea (Marbà et al., 1996 and Boudouresque, 2003) that has been documented over the last decades (Marbà et al., 1996 and Hemminga, and Duarte, 2000).

\subsection{Seagrass wrack formation and breakdown}

Seagrass plants generally shed their leaves annually in early autumn; the blades are initially buoyant, then sink and accumulate in drifts on the seabed (PIRSA, 2003). During periods of strong wind and wave activity, particularly in the winter months, surge and swell resuspends and mobilizes

\footnotetext{
${ }_{1}^{1}$ Marine Geology Department, Coastal Research Institute, National Water Research Center, 15 El-Pharanna Street, El-Shallalat, Postal code 21514, Alexandria, Egypt.

*Corresponding author E-mail: ayman_elgamal@yahoo.com

${ }^{2}$ Geography Department, Faculty of Art, Port Said University, Egypt.
} 
the detached leaf blades. Persistent onshore winds blow this drift-cast material into the surf zone and at high tide; it is washed onto the beach in clumps (PIRSA, 2003). When seagrass dies, it detaches from the bottom and forms what is known as wrack. Wrack remains on the shore for variable lengths of time or may become stranded above the high-water mark and accumulate over weeks or months forming large semi-permanent deposits. Consequently, large variations in wrack deposits occur from one location to another (Kendrick et al., 1995). It may be washed back into the sea during storm or high tide events, where it provides food for benthic coastal communities and fish species (PIRSA, 1999).

The breakdown of seagrass is important for nutrient cycling and productivity (Coccom 2007). Wracks of dead seagrass and algal material are physically broken down by wave and sand abrasion and are biologically decomposed by the action of bacteria and small invertebrates. Decomposition by bacteria releases organic matter and nutrients such as nitrogen and phosphorous (Tsimplis et al., 2006). These could be cause eutrophication in this marine system and may cause pluming of the growth of offshore seagrass meadows (Bell, 1983). Beach-cast seagrass accumulations are therefore typically long-lived, taking as many as 3 - 5 years to fully decompose into detrital matter. As a result, seagrass wrack may accumulate to a height of several meters and serve as a physical barrier between the sea and the dune system, reducing wave energy and providing a degree of protection to the foreshore (PIRSA, 1999).

\subsection{The problem of Seagrass wrack}

The slow breakdown of the wrack into organic matter can lead to unpleasant odors (Tsimplis et al., 2006). Wrack has traditionally been collected for use on gardens and to remove the "smell" as it begins to decompose CEN (2005). Moreover, the wrack is habitat for zooplankton which run on foots of tourists and swimmers in any popular recreational areas. Wrack accumulated in front of public land shall be collected (Tsimplis et al., 2006). The priority for harvesting, as in the case of beach cleaning, was determined as-needs basis and in specifically targeted areas where public amenity could be reduced due to large accumulations of wrack.

The problem of accumulation of dead Posidonia as seagrass wrack at beaches is not observed only at the North-West coast of Egypt but it perceived in the Mediterranean shores. The Mediterranean nearshore sandy and rocky bottoms are frequently colonized by Posidonia oceanica (L.) Delile, which is the most widespread seagrass of the Medirerranean basin (Bethoux and Cópin-Motegut, 1986; Pasqualini et al., 1998). The accumulation of seagrass and other marine macrophyte material in beaches and the banquette destruction have been reported elsewhere, such as in Australia, South Africa and the Netherlands (Ochieng, 1999; Pellikaan, 1984). The accumulation of beach cast litter a result of the interaction between seagrass ecology and physical factors such as winds, currents and waves.

The aim of this work is to assess the environmental consequences of the climatic variables on Posidonia wrack and the best ways to control. The case study is the Egyptian North Western Coast, in particular Garawla Islands Village east of Mersa Matrouh City, which have more threads of Posidonia wrack on the beaches. 


\section{Site Description}

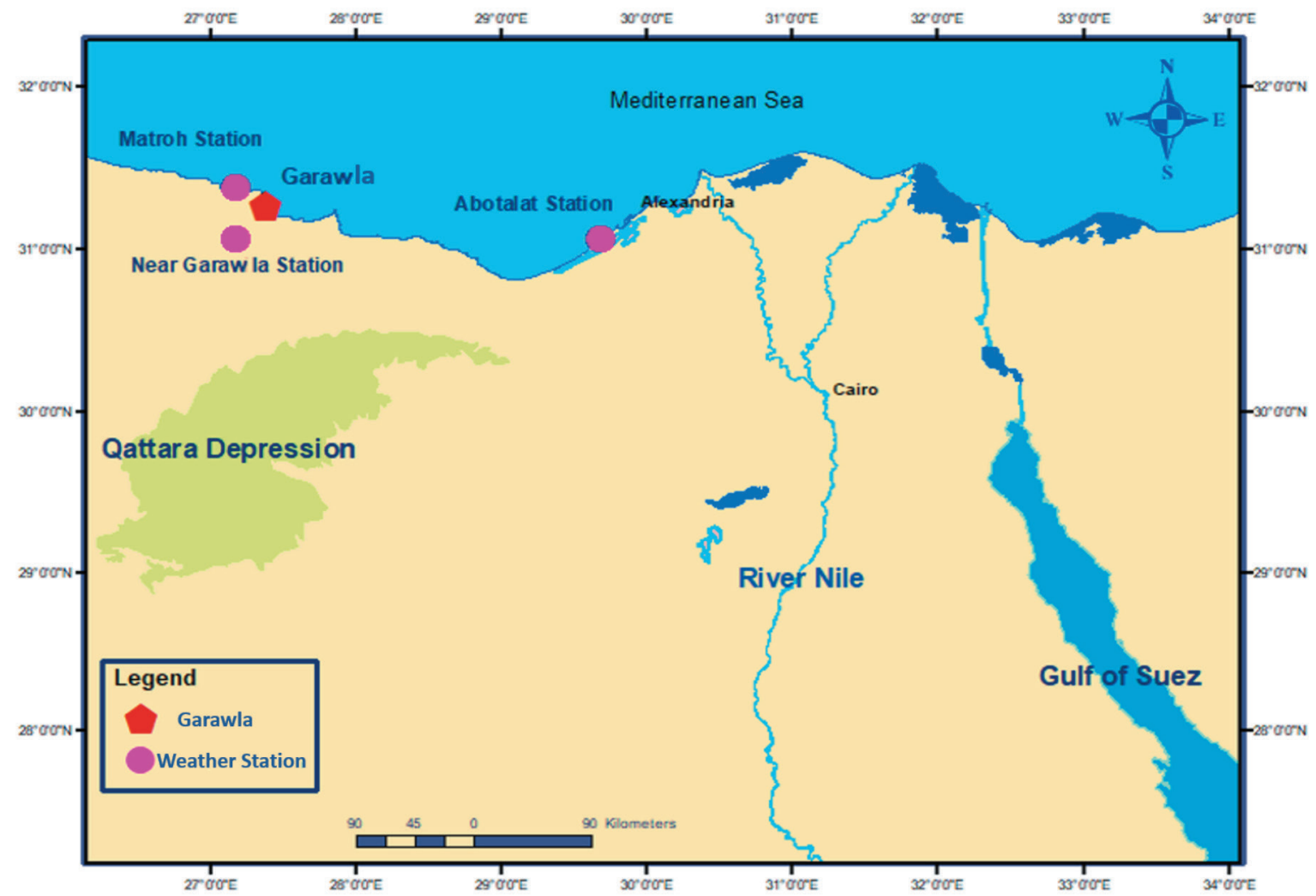

Figure 1. Base map of the sites under investigation.

Garawla Islands Village located at AlexandriaMatrouh coastal road between 270.05 to 270.76 $\mathrm{km}$ from Alexandria. The surf and breaker zone are composed of sand/rocks. It has sandy beach surrounded by rock as the two sides. The weathering data were collected from three different weathering stations. These are Matrouh stations, Near Garawla station and Abotalat station. The coordination of the weathering station areas is listed in Table 1.

Table 1. Coordination of the three weathering station areas under investigation

\begin{tabular}{|c|c|c|c|c|c|c|}
\hline Station & location & Longitude & Latitude & location & Longitude & Latitude \\
\hline Matrouh & $\begin{array}{c}\text { North-east } \\
\text { corner }\end{array}$ & 27.3162 & 31.3886 & $\begin{array}{c}\text { South-west } \\
\text { corner }\end{array}$ & 27.1706 & 31.3323 \\
\hline Near Garawla & $\begin{array}{c}\text { North-east } \\
\text { corner }\end{array}$ & 27.4089 & 31.1962 & $\begin{array}{c}\text { South-west } \\
\text { corner }\end{array}$ & 27.1628 & 31.0539 \\
\hline Abotalat & $\begin{array}{c}\text { North-east } \\
\text { corner }\end{array}$ & 29.7137 & 31.08 & $\begin{array}{c}\text { South-west } \\
\text { corner }\end{array}$ & 29.6841 & 31.0656 \\
\hline
\end{tabular}




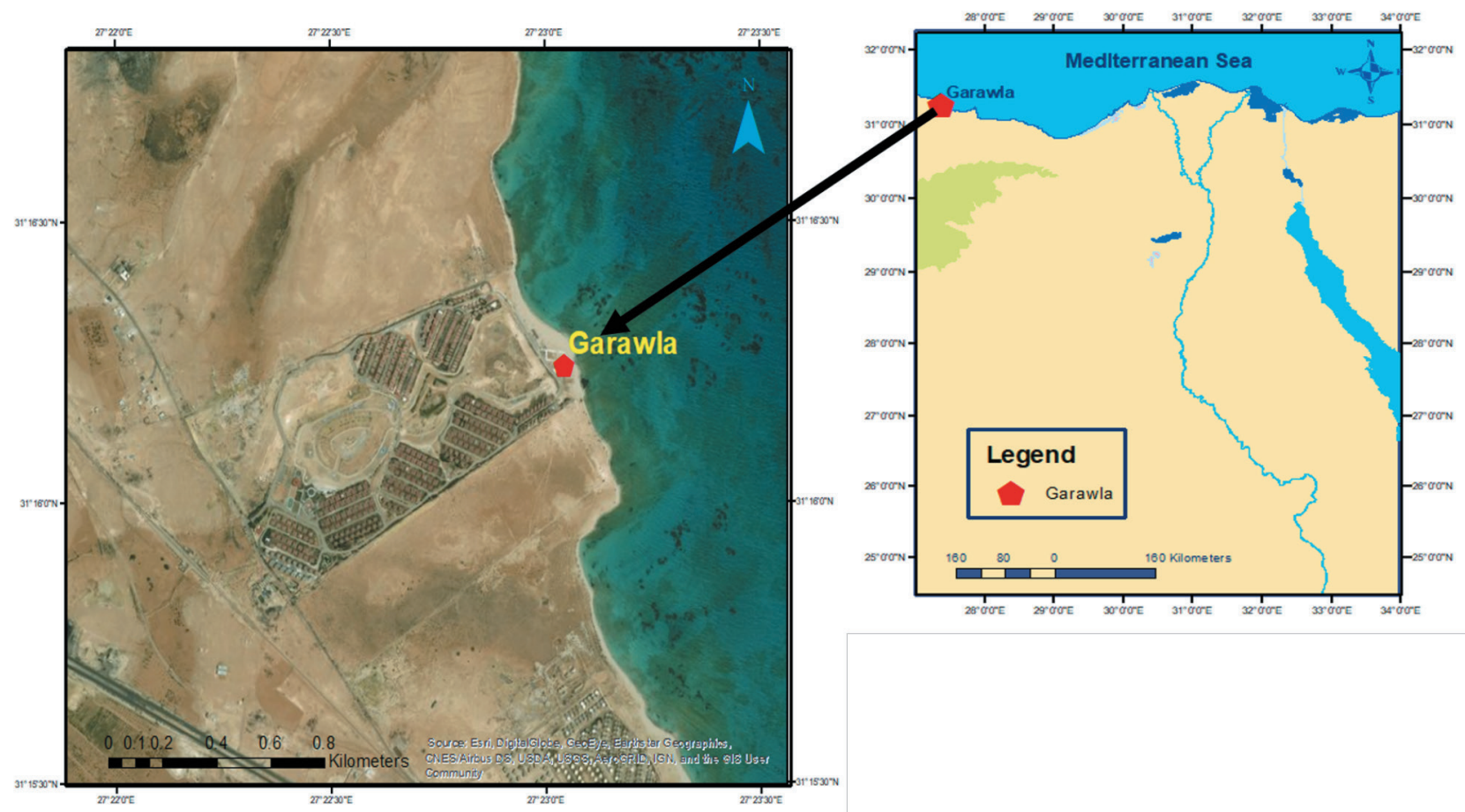

Figure 2. Garawla Islands village

\section{Assessment technique}

The assessment was carried out according to a prescribed methodology. The standard approach for comparing beach litter pollution has been used to assess Posidonia wrack distribution in the beaches of Garawla Islands village based on data collected from field as described by Earll (Cardoso et al., 2005). The methodology is stipulated the parameters to be measured including area covered, time, methods of estimating amount of wrack, species composition of wrack, likely impact on beach ecology (PIRSA, 2003). Also, it has to identify the locations of the largest wrack accumulations (PIRSA, 1999). The maps of the area under investigation were taken from Google Earth program. Identification and clarification of the colonies of Posidonia were carried out using GIS technology.

The assessment takes into consideration the nature, amount, function and turnover rate of the wrack available at the site. Regard must be given to whether the wrack is persistent or highly mobile and the likelihood and rate of replenishment. This information will be used to determine whether the wrack accumulation may be harvested sustainably from an area according to best available evidence (PIRSA, 2003).

Geometric correction was carried out for satellite images using image to image correction technique. Enhancement and classification of the satellite images was executed by supervised classification method for the years 1997, 2005 and 2013 using the Geographical Information System Software Arc Map. The study area coordination was in the corners of Lat:31 $15 / 51 / / \mathrm{N}$, Long: 27 $33 / 04 / / \mathrm{E}$, Lat: $31^{\circ} 07 / 49 / / \mathrm{N}$, Lon: $27^{\circ} 25 /$ 58// E, Lat:31 $19 / 22 / / \mathrm{N}$, Lon: $27^{\circ} 12 / 44 / /$ E, Lat:31 $25 / 42 / / N$, Lon: $27^{\circ} 21 / 18 / /$ E. The comparison among the three years was built on image processing of satellite image taken from Landsat at the same month (August) with the conditions as listed in table 2. Statistical analysis and analysis of variance test were executed using Statgraph software. 
Table 2. Image conditions used for comparison of the coastal plants during the three years.

\begin{tabular}{|c|c|c|c|c|c|c|}
\hline Row & Path & Source & Type & Satellite & month & years \\
\hline 51 & 178 & USGS & TM & Landsat & Aug & 1997 \\
\hline 50 & 178 & USGS & ETM & Landsat & Aug & 2005 \\
\hline 51 & 178 & USGS & ETM & Landsat & Aug & 2013 \\
\hline
\end{tabular}

\section{Results and Discussion}

\subsection{Climatic conditions}

The Egyptian Mediterranean coast is famous by coastal plants including the seagrass. This coastal area is characterized by special Mediterranean climate, which is subject to change with the global climate change. Maximum and minimum temperature values were measured at three weathering stations around the study area were Matrouh, Abu Talat, and near Garawla stations. Figure3 shows maximum and minimum temperature values with solar intensity distribution among the three stations during 2013. The minimum and maximum temperature values at the study area. These stations were 5.49 and $43.56^{\circ} \mathrm{C}$ during 2013 , respectively. The average values and its standard deviation with their range of precipitation, wind speed, relative humidity and solar intensity during 2013 were $0.24 \pm 1.64$ $\mathrm{mm}, 4.41 \pm 1.34 \mathrm{~m} / \mathrm{s}, 0.58 \pm 0.13$ fractions and $21.59 \pm 7.47 \mathrm{MJ} / \mathrm{m}^{2}$ and their ranges were $0-24.99$ $\mathrm{mm}, 1.87-9.94 \mathrm{~m} / \mathrm{s}, 0.13-0.85$ fractions, and $2.55-30.75 \mathrm{MJ} / \mathrm{m}^{2}$, respectively. Mean values of temperature, relative humidity and solar intensity were presented as contour lines in the area of study among the three weathering stations as in Figures $3 \mathrm{a}, 3 \mathrm{~b}$ and $3 \mathrm{c}$.

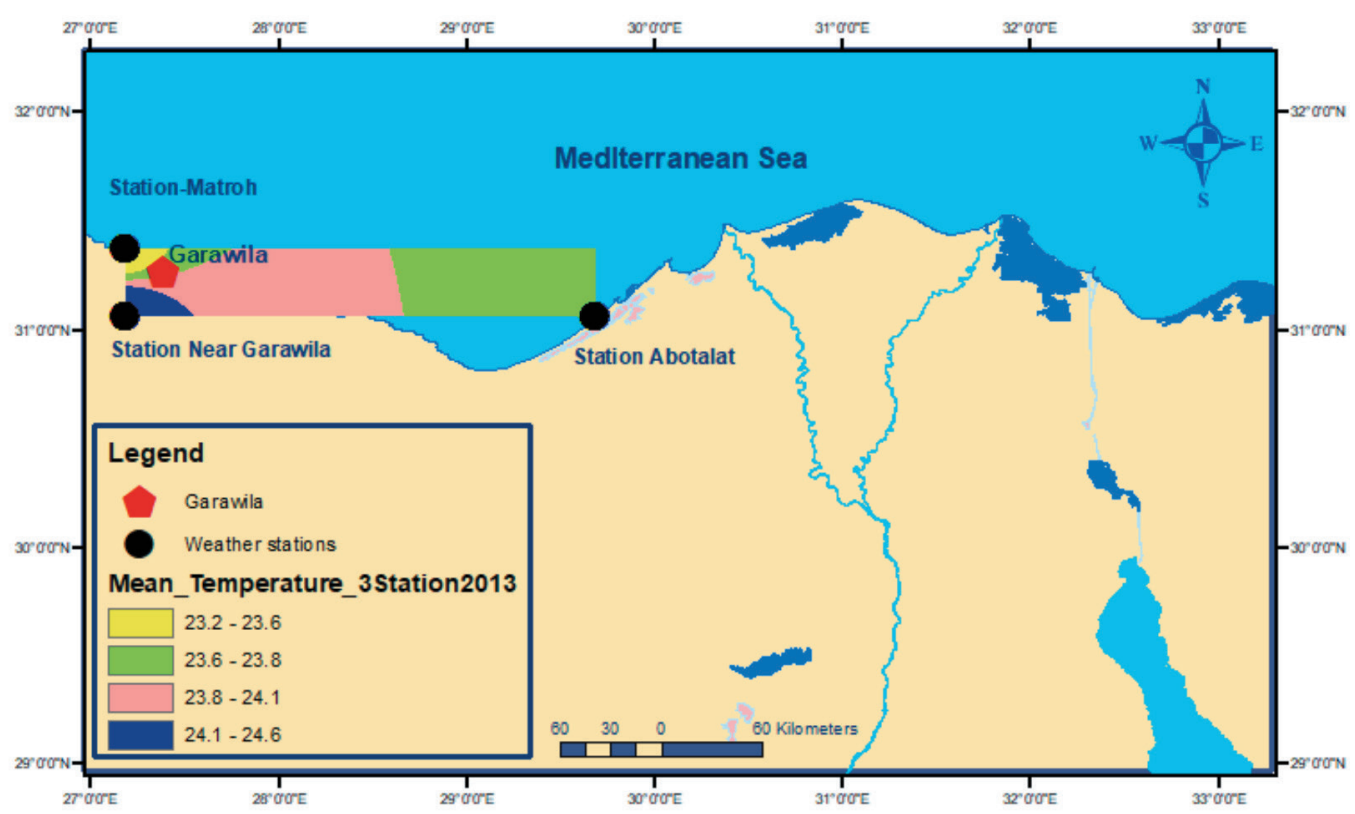

Figure 3a. Mean temperature distribution in study area during 2013 


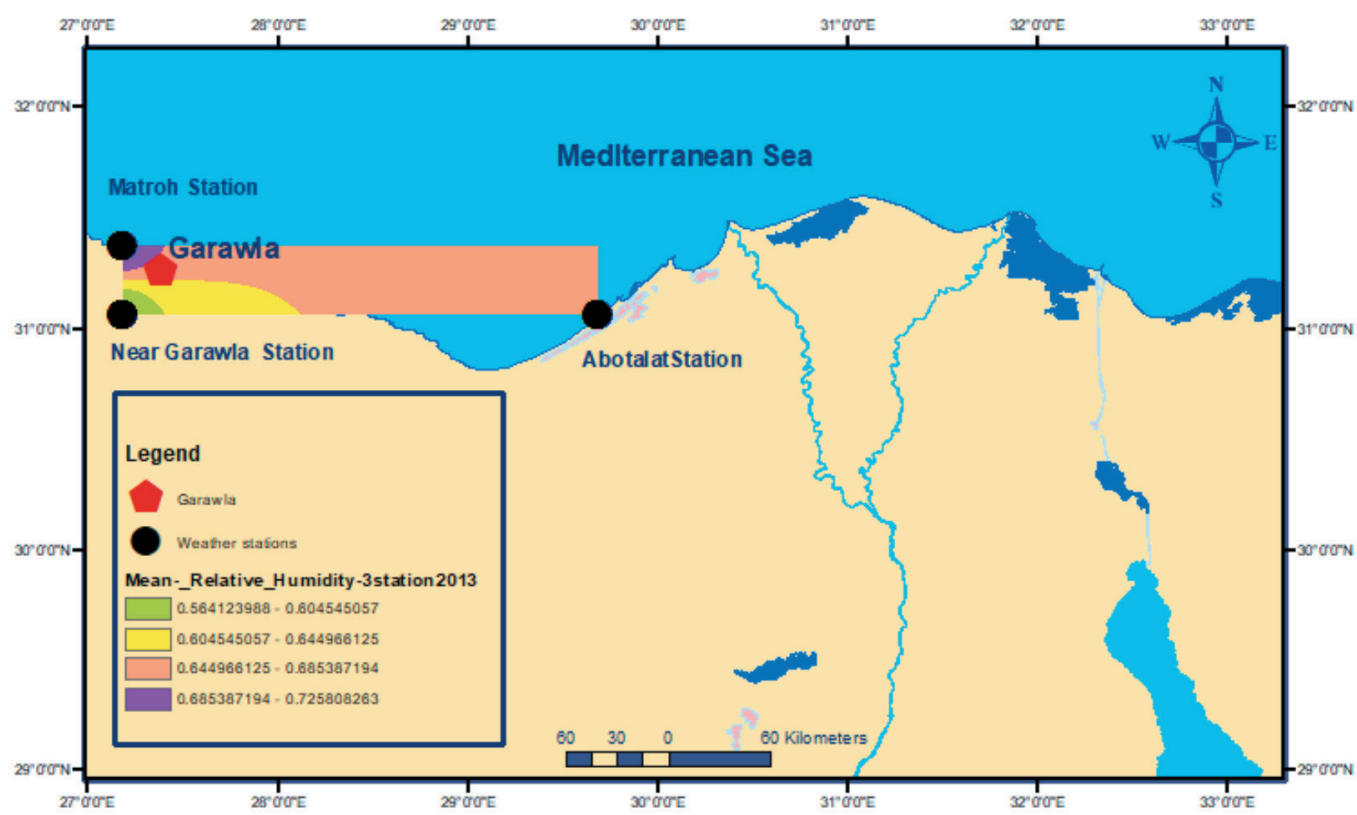

Figure 3b. Mean relative humidity distribution in study area during 2013.

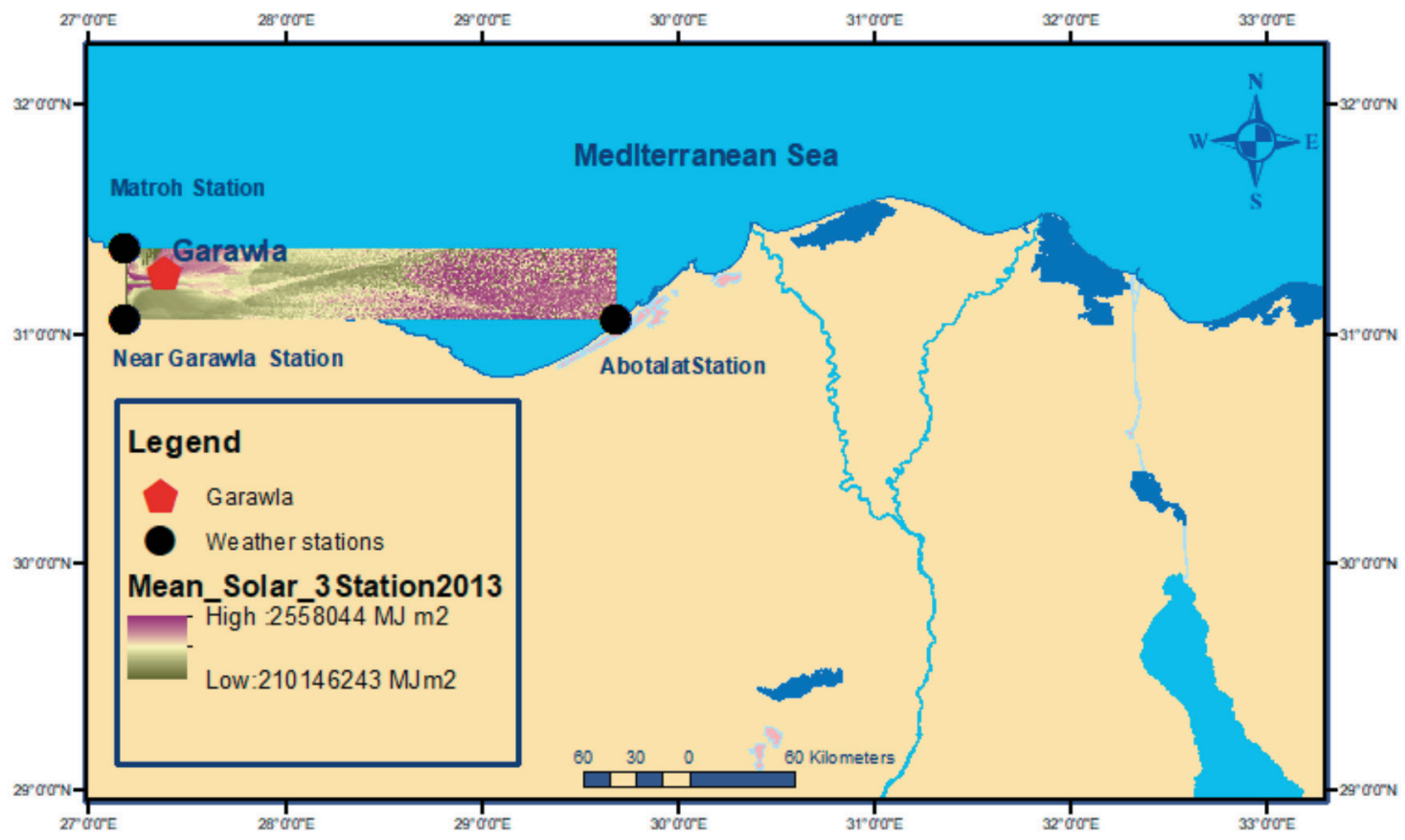

Figure 3c. Mean solar intensity distribution in study area during 2013. 


\subsection{Temporal variation of climatic conditions}

Different climatic conditions were investigated through three years; 1997, 2005 and 2013. Figures 4-7 show the Box and Whisker plots of the groups of daily values over the three years of maximum and minimum values of temperature $\left({ }^{\circ} \mathrm{C}\right)$, wind speed $(\mathrm{m} / \mathrm{s})$, solar intensity $(\mathrm{MJ} / \mathrm{m} 2)$, relative humidity (fraction) and precipitation ( $\mathrm{mm}$ ). It represents the year 2013 has the relatively higher temperature values than the other years. Table 3 list the yearly averages of maximum and minimum temperature, wind speed, relative humidity and solar intensity of near Garawla station during 1997, 2005 and 2013. Minimum temperature values were presented in Figure 5 during the three years.

\subsubsection{Temperature}

The distribution of maximum values of temperature during years 1997, 2005 and 2013 in the near Garawla Islands Village weathering station is presented in Figure 4. The minimum and maximum of temperature values of the three years were accumulated as groups and presented as box and Whisker plots (Figure 5). Analysis of variance (ANOVA) was executed to test of significant differences between the daily maximum and minimum temperature values within the three years. The F-ratio, which in this case equals 431.805 , is a ratio of the betweengroup estimate to the within-group estimate.
Since the P-value of the F-test is less than 0.05 , there is a statistically significant difference between the means of the 6 variables of minimum and maximum temperature values within the three years at the $95.0 \%$ confidence level. A Fisher's least significant difference (LSD) procedure was applied as multiple comparison procedure to determine, which means are significantly different from which others. No statistically significant difference among the minimum values of the three years and they appear as homogenous groups but they have significant difference at the $95.0 \%$ confidence level between them and the maximum values of the three years. Within the maximum temperature values, 2013 has statistically significant difference with 1997 and 2005 data. 2013 was observed as the relatively higher values of temperature among the other two years as shown in Figure 5.

Table 3. Yearly average of maximum and minimum temperature, wind speed, relative humidity and solar intensity of Near Garawila station during 1997, 2005 and 2013.

\begin{tabular}{|c|c|c|c|c|c|}
\hline Year Average & $\begin{array}{c}\text { Max } \\
\text { Temperature }\end{array}$ & $\begin{array}{c}\text { Min } \\
\text { Temperature }\end{array}$ & Wind & $\begin{array}{c}\text { Relative } \\
\text { Humidity }\end{array}$ & Solar \\
\hline 1997 & 25.19 & 14.38 & 4.38 & 0.60 & 20.90 \\
\hline 2005 & 25.58 & 14.98 & 4.68 & 0.59 & 20.97 \\
\hline 2013 & 26.77 & 14.45 & 4.31 & 0.78 & 21.04 \\
\hline
\end{tabular}




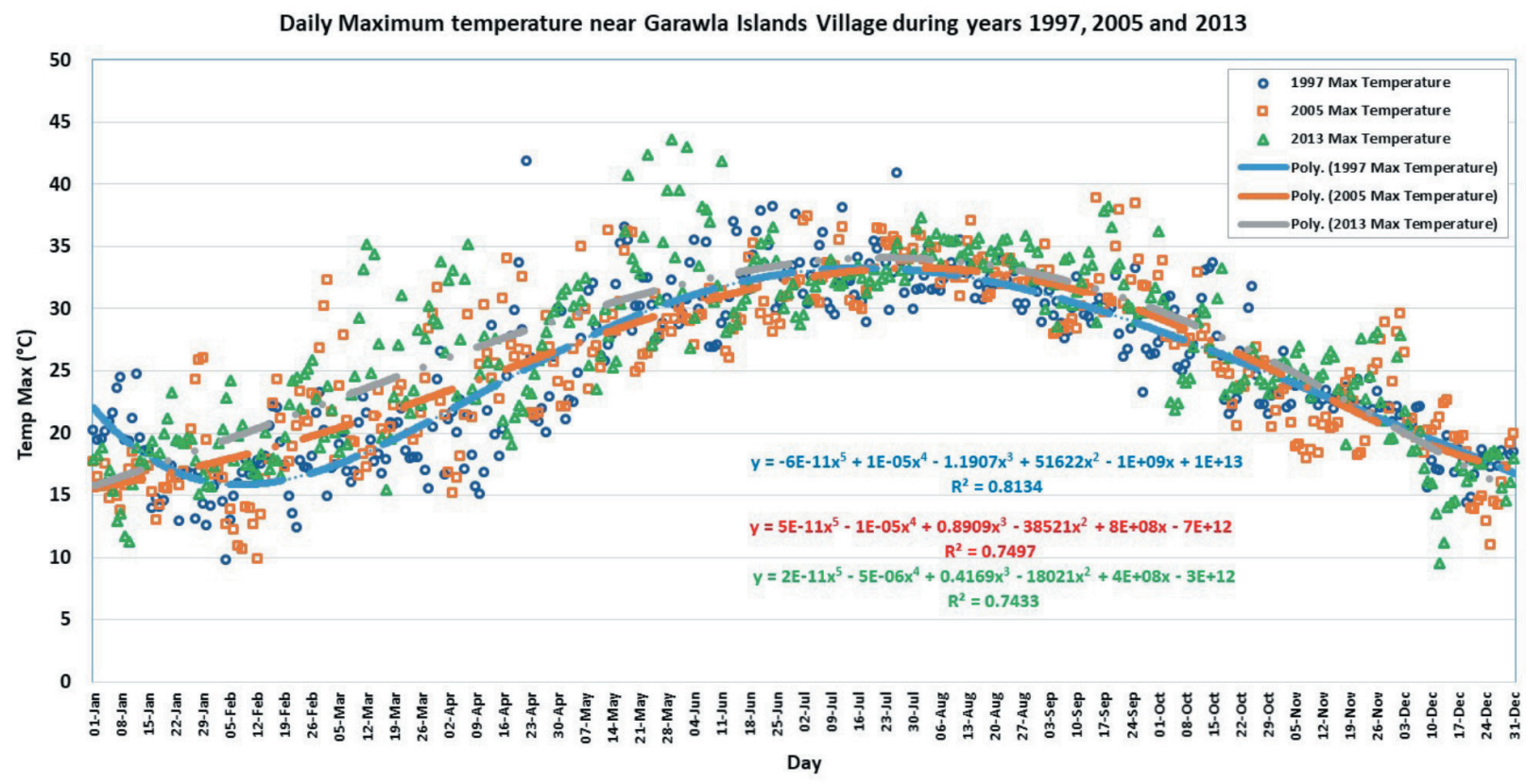

Figure 4. Daily Maximum temperature near Garawla Islands village during 1997, 2005 and 2013.

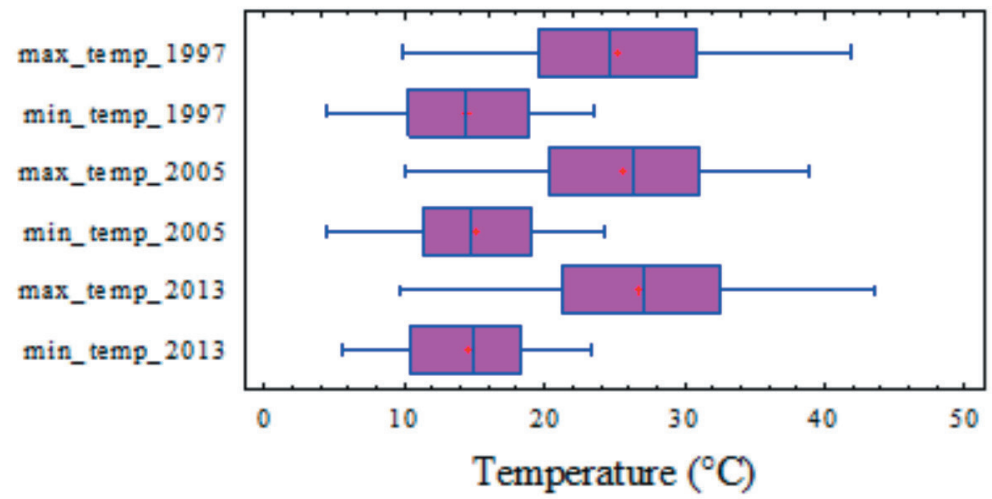

Figure 5. Box and Whisker plot of values of daily maximum and minimum temperature

\subsubsection{Humidity}

The relative humidity during years 1997, 2005 and 2013 in the near Garawla Islands Village weathering station is presented as box and Whisker plot (Figure 6). Analysis of variance (ANOVA) was executed to test of significant differences between the daily relative humidity values within the three years. The F-ratio in this case equals 2.63 Since the P-value of the F-test is greater than or equal to 0.05 , there is not a statistically significant difference between the means of the 3 daily variables of relative humidity over the three years at the $95.0 \%$ confidence level and they appear as homogenous groups. Relative humidity values were characterized by low outliers during the three years and 2013 appeared as the wider range. 


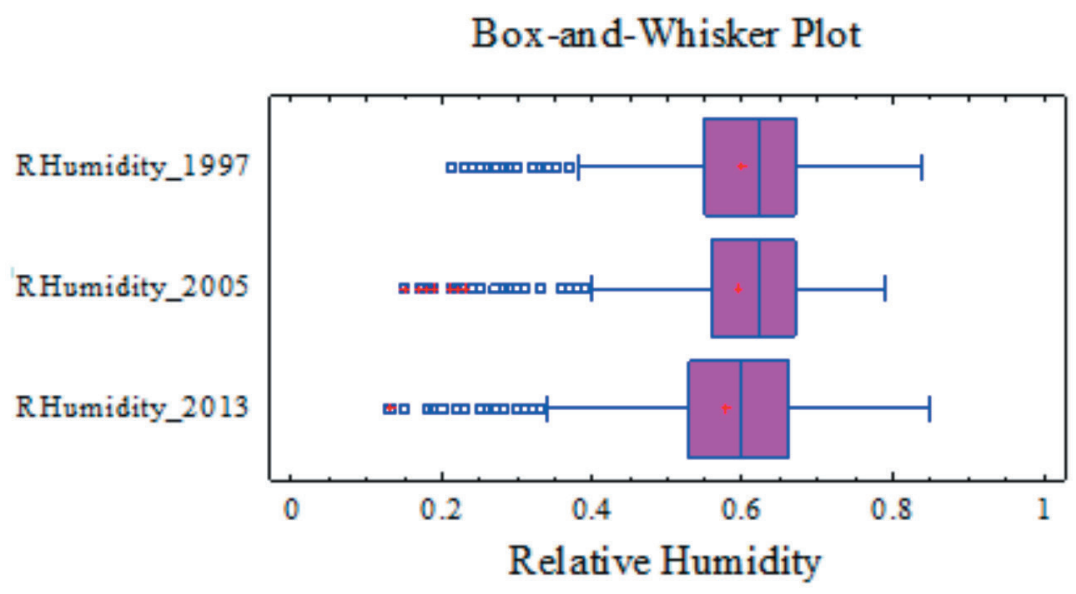

Figure 6. Box and Whisker plot of values of daily relative humidity (fractions) during 1997, 2005 and 2013.

\subsubsection{Solar intensity}

The distribution of solar intensity values during years 1997, 2005 and 2013 in the near Garawla Islands Village weathering station is presented in Figure 7. Solar intensity values were accumulated as groups and presented as box and Whisker plot (Figure 8). Analysis of variance (ANOVA) was executed and the F-ratio equals 0.81 Since the $\mathrm{P}$-value of the F-test is greater than or equal to 0.05 , there is not a statistically significant difference between the means of the 3 variables years at the $95.0 \%$ confidence level and they appear as homogenous groups. It is observed that the solar intensity values during 2013 was shifted toward higher values compared with the other two years as show in Figure 8.

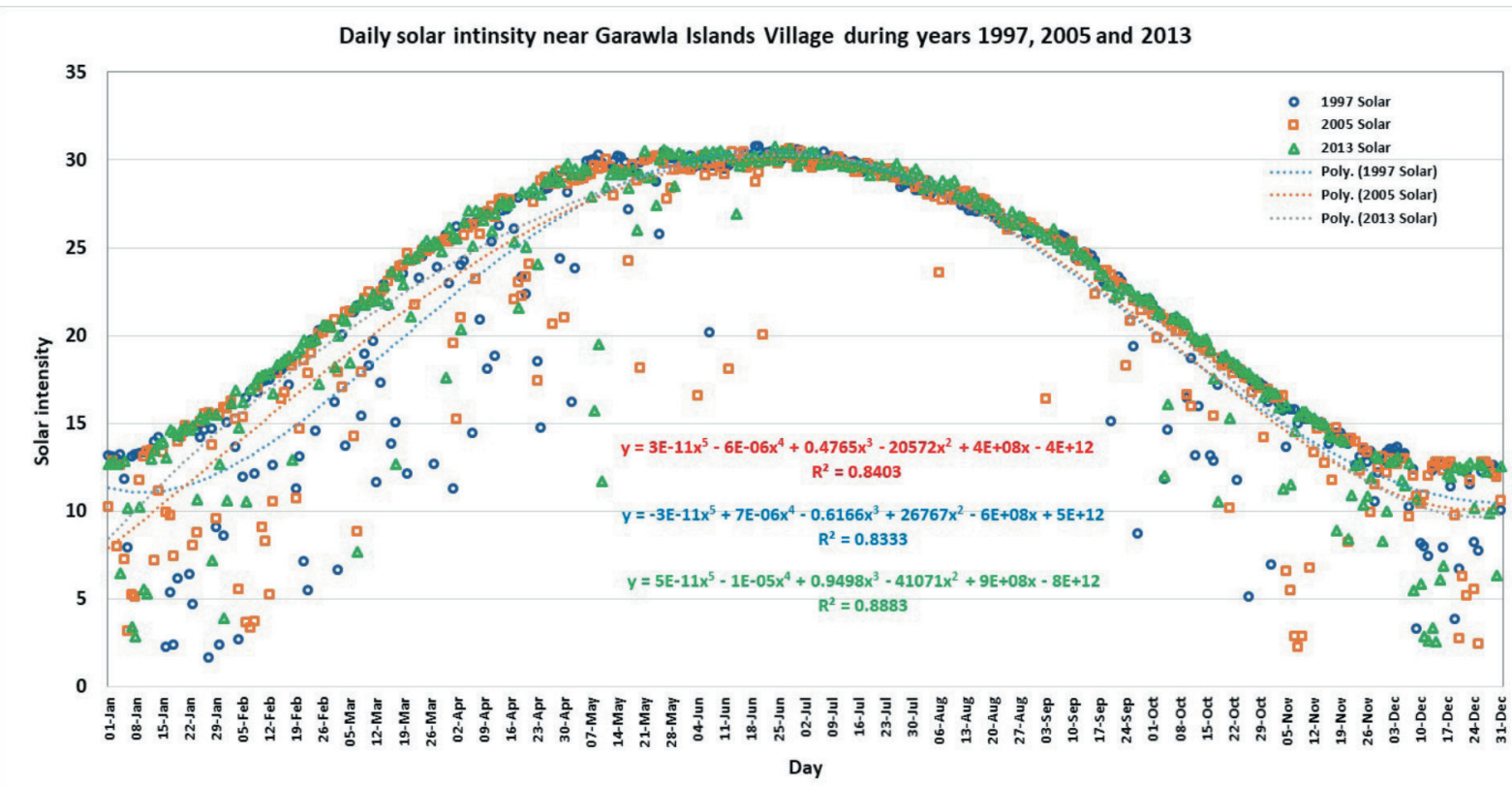

Figure 7. Daily Maximum temperature near Garawla Islands village during 1997, 2005 and 2013 


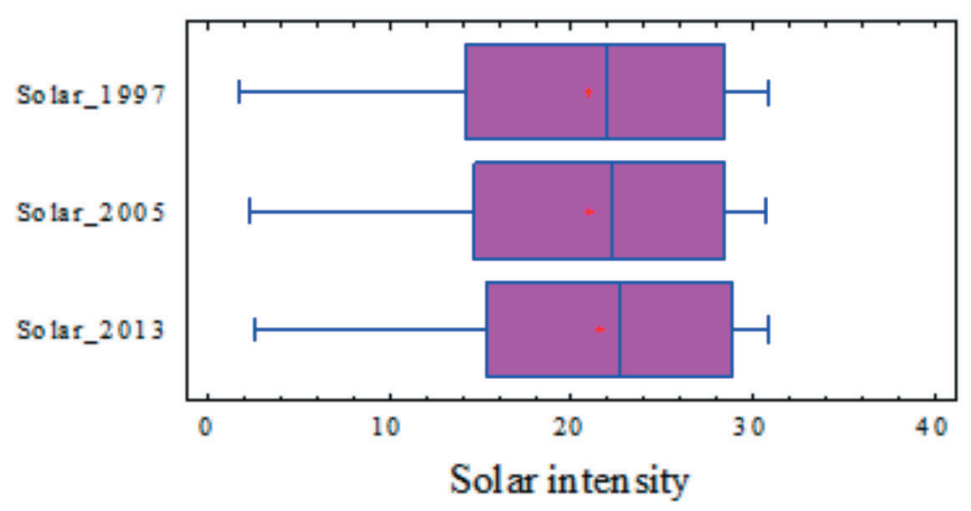

Figure 8 . Box and Whisker plot of values of daily solar intensity (MJ/m2) during 1997, 2005 and 2013.

\subsubsection{Wind speed}

The wind speed values during years 1997, 2005 and 2013 in the near Garawla Islands Village weathering station is presented as box and Whisker plot (Figure 9). Analysis of variance (ANOVA) was executed and the F-ratio equals 5.77 Since the P-value of the F-test is less than 0.05 , there is a statistically significant difference between the means of the year's values at the 95.0\% confidence level. LSD procedure was applied and indicated that the data of year 2005 has statistically significant difference at the $95.0 \%$ confidence level between them and the other two years. The wind speed values of the three years were characterized by presence of higher outliers as shown in Figure 9.

\subsubsection{Precipitation}

The distribution of precipitation values during years 1997, 2005 and 2013 in the near Garawla Islands Village weathering station is presented in Figure 10. Shift of the starting of the precipitation period during the years was observed. Delay of the real starting was clearly noticed as the first rain in 1997 was on 20 September 1997, while it started in 2005 on 16 October 2005 and in 2013 on 7 November 2013. This is one of the consequences of the climate change.

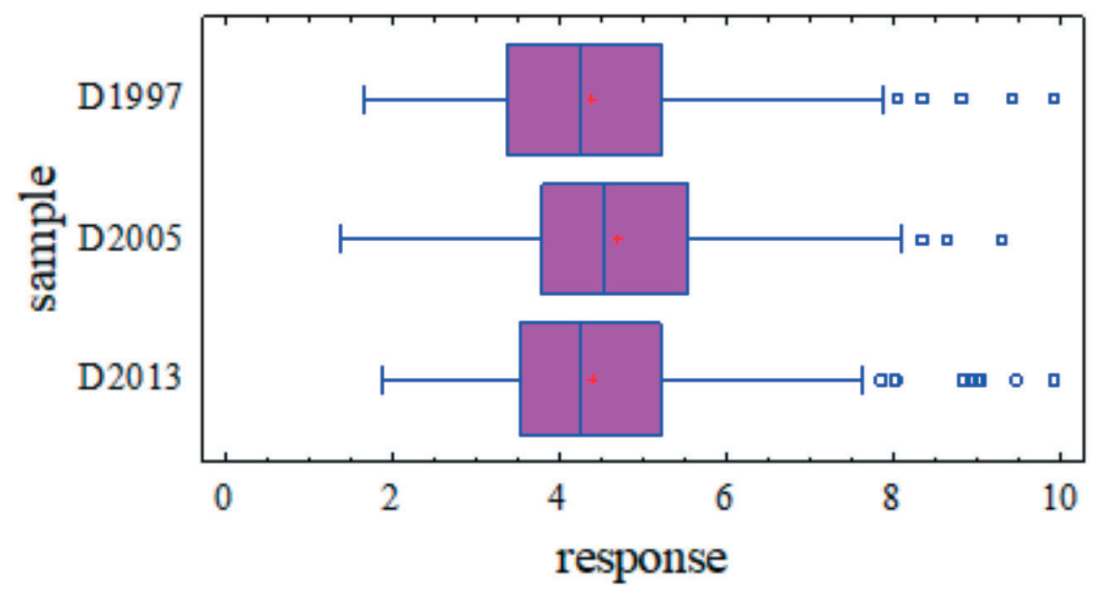

Figure 9. Box and Whisker plot of values of daily wind speed $(\mathrm{m} / \mathrm{s})$ during 1997, 2005 and 2013. 


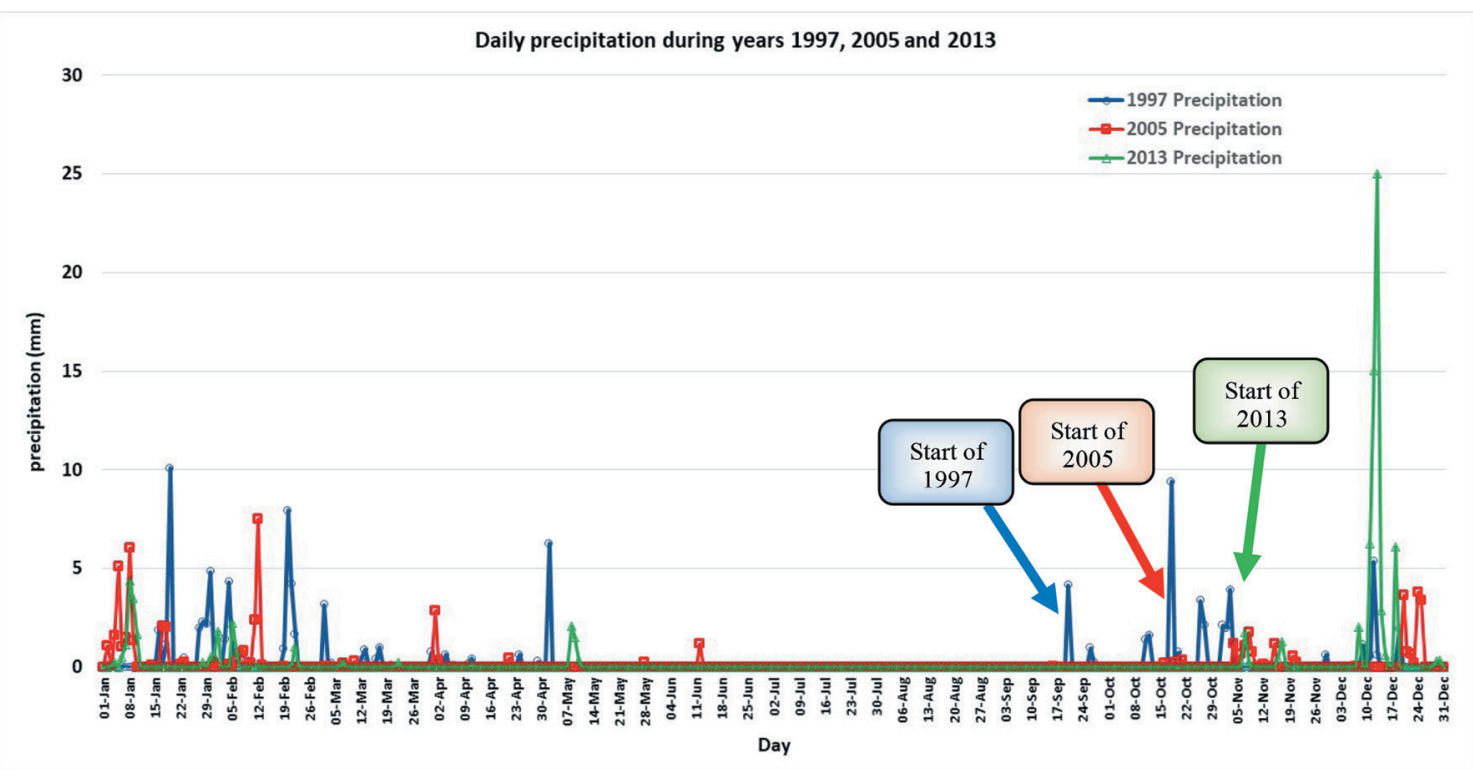

Figure 10. Daily precipitation near Garawla Islands village during 1997, 2005 and 2013.

\subsection{Posidonia distribution}

\subsubsection{The identification of the seagrass type:}

The observed seagrass species is identified as Posidonia oceanica (L.) Delile, which is classified under the family Posidoniaceae [32]. Huge amount of dead Posidonia oceanica accumulated as patches at the area under investigation at the beach of Garawla Islands Village, east of Mersa Matrouh City. The accumulated Posidonia make aggregation called wrack. Figure 11 shows the Posidonia wrack at the beach of Garawla Islands Village.

\subsubsection{Distribution of coastal Posidonia at Garawla Islands Village:}

Posidonia was distributed in the backshore as patches and as accumulated as wrack. The Posidonia wrack contains more than thousands of dead leafs, considered as highly polluted areas. As shown in Figure 12, different sites at the beach of Garawla Islands Village have Posidonia wrack and by wind, dead Posidonia leaves were scattered in the backshore area.

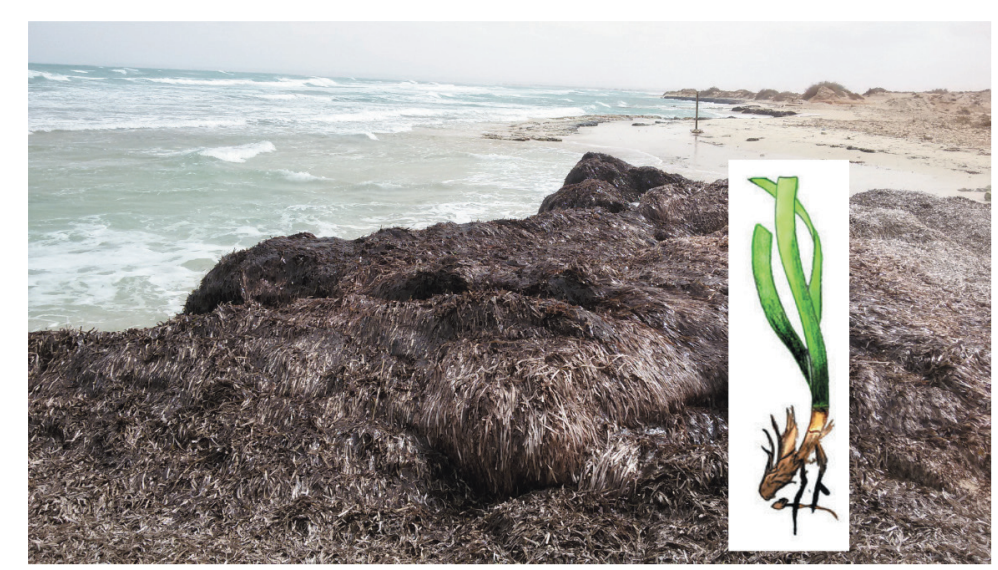

Figure 11. Posidonia wrack in the beach of Garawla Islands Village. 


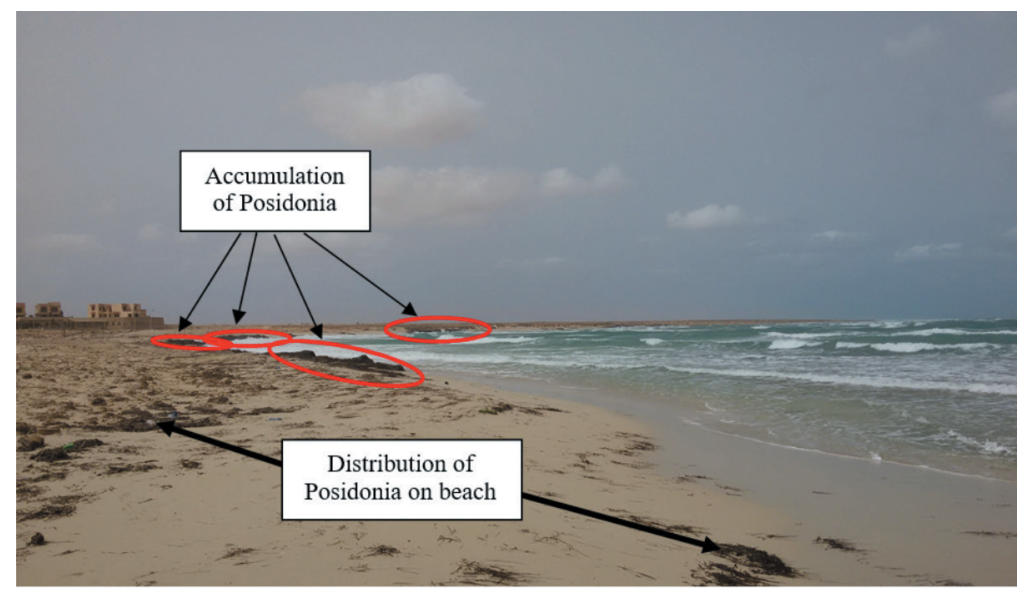

Figure 12. Patches and wrack of Posidonia in the backshore area of Garawla Islands Village

The investigation of the sources of the Posidonia wrack revealed that Posidonia colonies were found at the near shore area of the village as shown in Figure 13. The important aggregation of these patches is present in the surf, breaker and offshore zone at surf zone as shown in Figures 13 and 14. These patches are the main source of the Posidonia wrack.

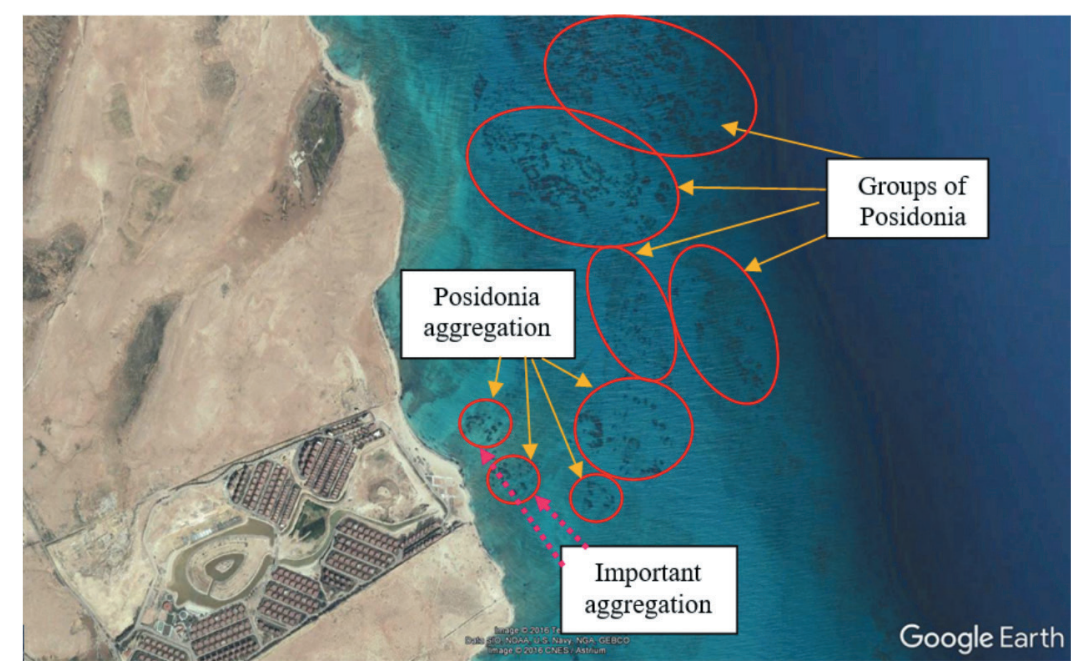

Figure 13. Aggregation of Posidonia in the coastal area of Garawla Islands Village.

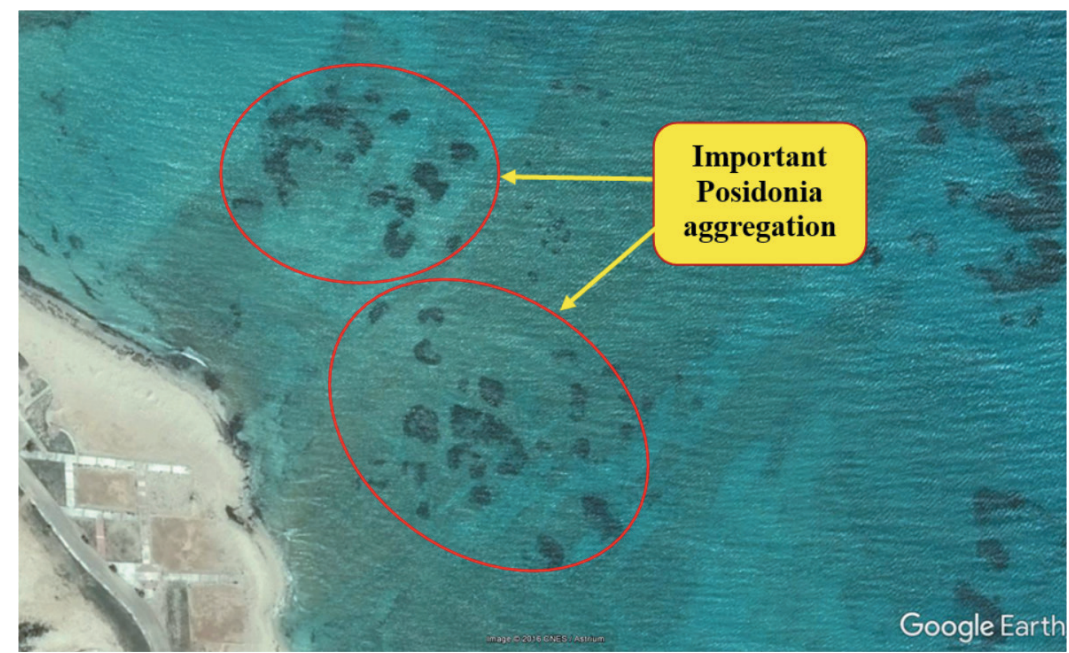

Figure 14. The near shore aggregation of Posidonia at Garawla Islands Village coastal area. 


\subsubsection{Control of Posidonia wrack:}

Firstly, the residential Posidonia wracks have to be removed mechanically because it will be a source of Posidonia for the next sites and could return back to the near shore area. The area of study is touristic area. Therefore, to control accumulation of the dead Posidonia at beaches, elimination nets can be used as barrier of the swimming area of the beach and to prevent suspended leafs to reach the beach. The western north coast of Egypt has wide variety of geomorphology. In the case of Garawla Islands Village, the beach is differentiated into rocky shore and sandy beach as shown in Figure 15. The sandy beach can be isolated by net to prevent the colloidal movable sea grasses to park at this sandy beach. The net can be installed on the rocks surrounded the sandy beach part as shown in Figure 16. The proposed net has to fix at sea bed with carefully design to adapt with the tide. The net composed of floating objects connected with hard heavy-duty plastic net by strong zip ties. According to depth, successive hard plastic nets were connected together by elastic heavy-duty plastic net to compensate the up and down oscillation of the sea surface during tidal motion. The last layer of the hard-plastic net is fixed to the bed by junction of leather belt fixed to the bed by cuttings of woody plants as live staking (cuttings of woody plants). Figure 17 , demonstrate the proposed net to use as barrier between the transported Posidonia and the beach under investigation. These nets also can prevent the jelly fish to visit these beaches.

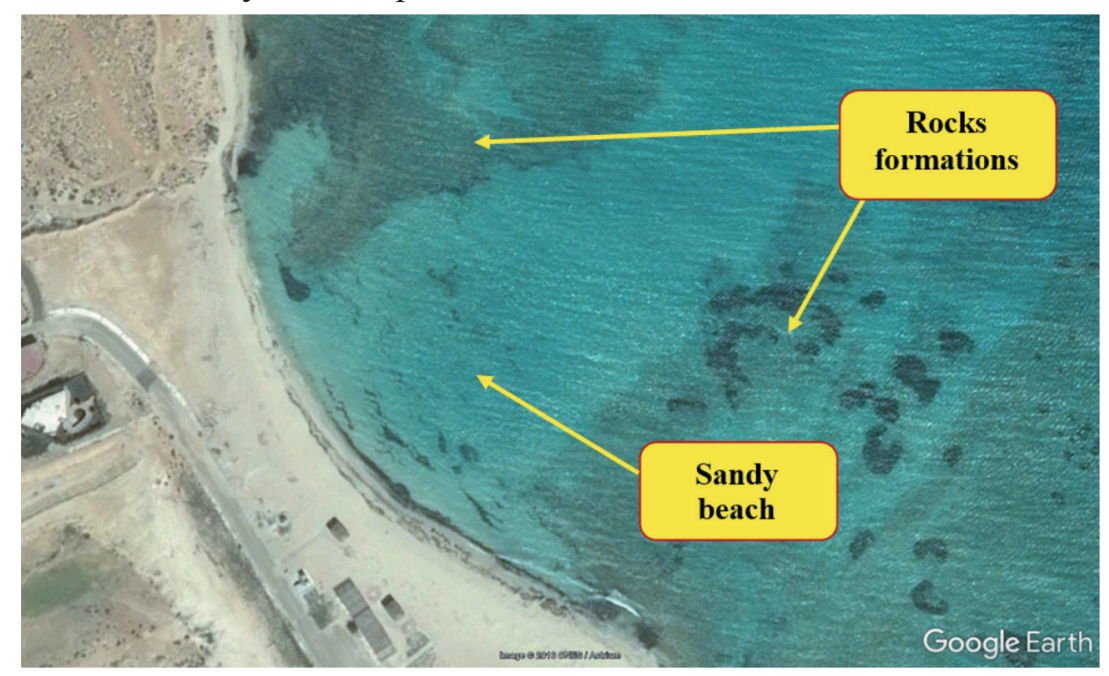

Figure 15. The sand/rocky coastal area of Garawla Islands Village.

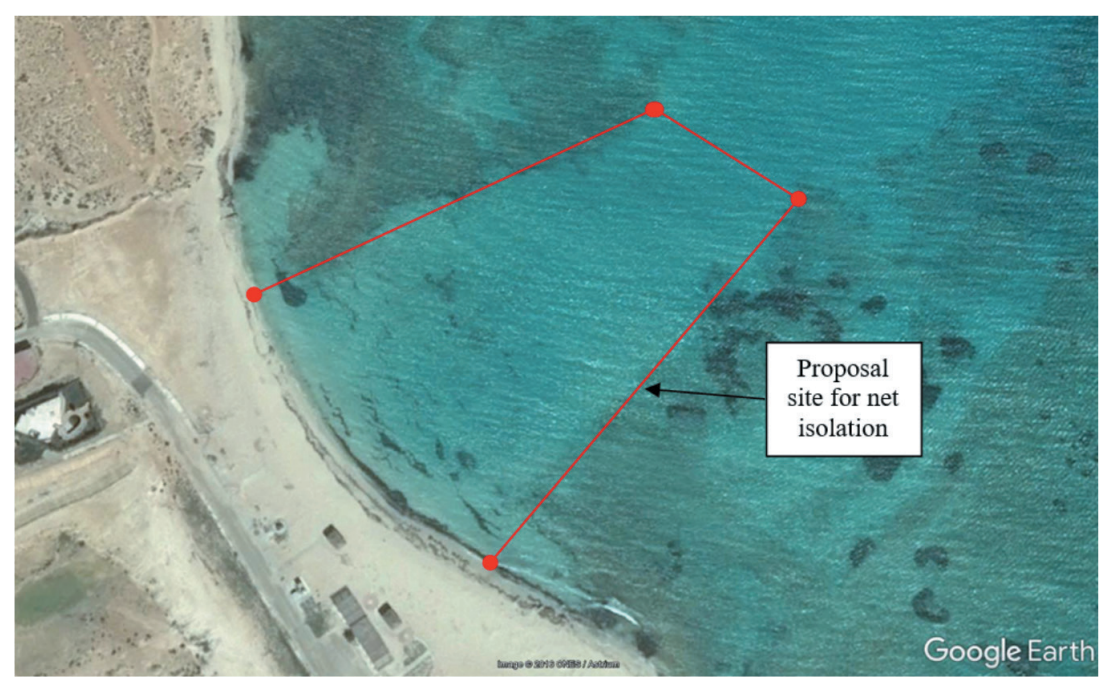

Figure 16. The recommended site for the net isolation. 


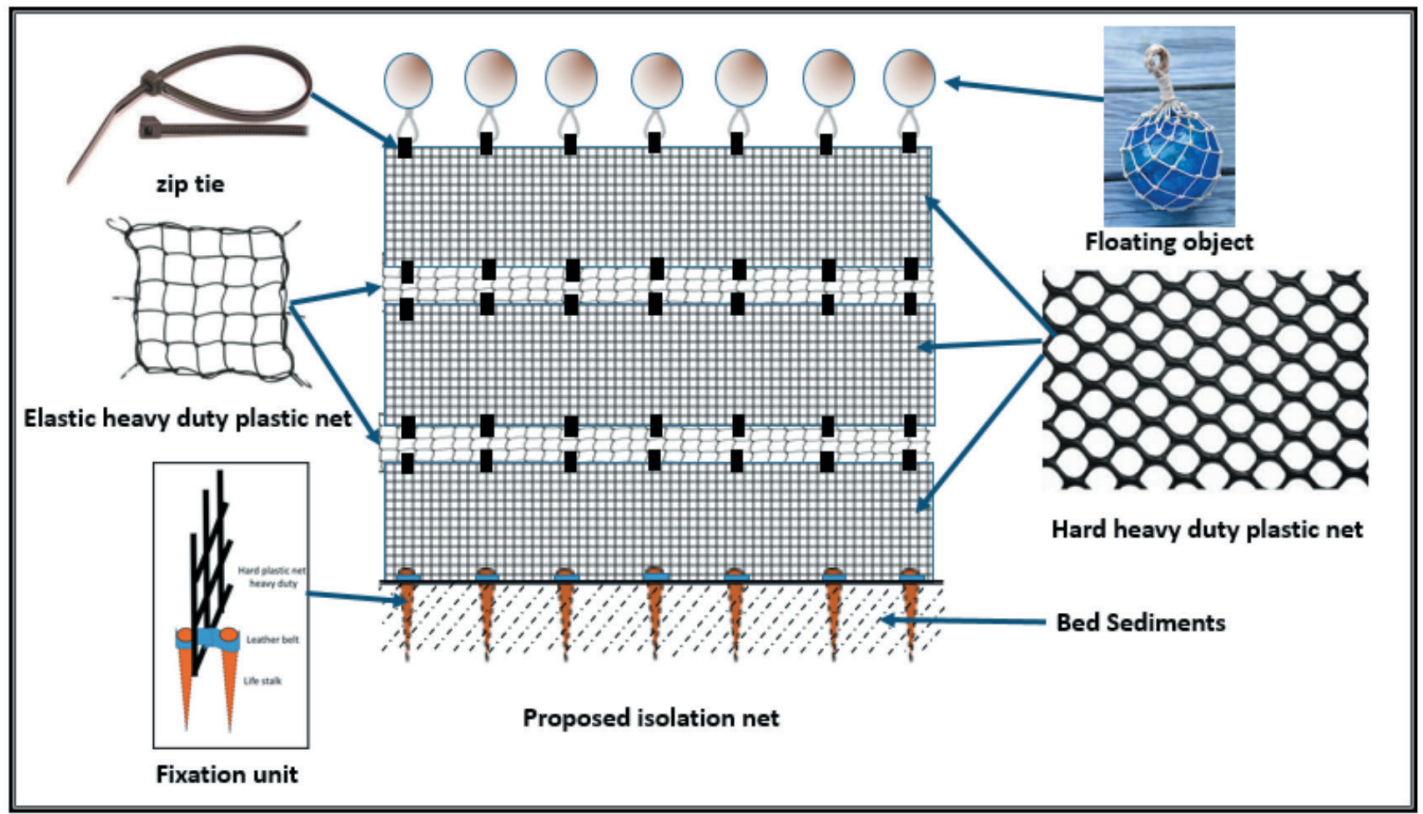

Figure 17. The proposed isolation nets.

\subsubsection{Climate change and its effects on the distribution of Posidonia}

Firstly, Carbon dioxide is very important parameter affect the climate change. The increase of effluents of it gives more greenhouse effects. Increase of carbon dioxide in air can alter the normal concentration of it in seawater to increase. This increase will result the acidification phenomena due to formation of carbonic acid. Perhaps Posidonia is plant, which consume the carbon dioxide present in the water and increase the oxygen. For this reason, the community of healthy Posidonia play an important role to decrease acidification of the coastal area. Tsimplis and his team review recent changes in the oceanography attributed to climate variability (Tsimplis et al., 2006).

\subsubsection{Temporal variation of coastal plants}

The Geographical Information System Software Arc Map was used to differentiate between the coastal plants during the August of three years. Figure 18 shows the distribution of coastal plant cover of the coastal strip during 1997, 2005 and 2013 years. The software counts the pixels, which represent the coastal plants. The investigation of the temporal variation of the coastal plants revealed that 2013 is the higher amounts of coastal plants including dead Posidonia and its wrack as shown in Figure 19. This indicated to the increase of amounts of dead Posidonia in its habitat and continuous reduction of its counts in their community. This is may be due to the climate change and the climatic conditions at the area of study such as the relatively higher temperature with time. This also, due to the change of the ecological and physical oceanographic factors of the sea such as waves, currents and winds. 


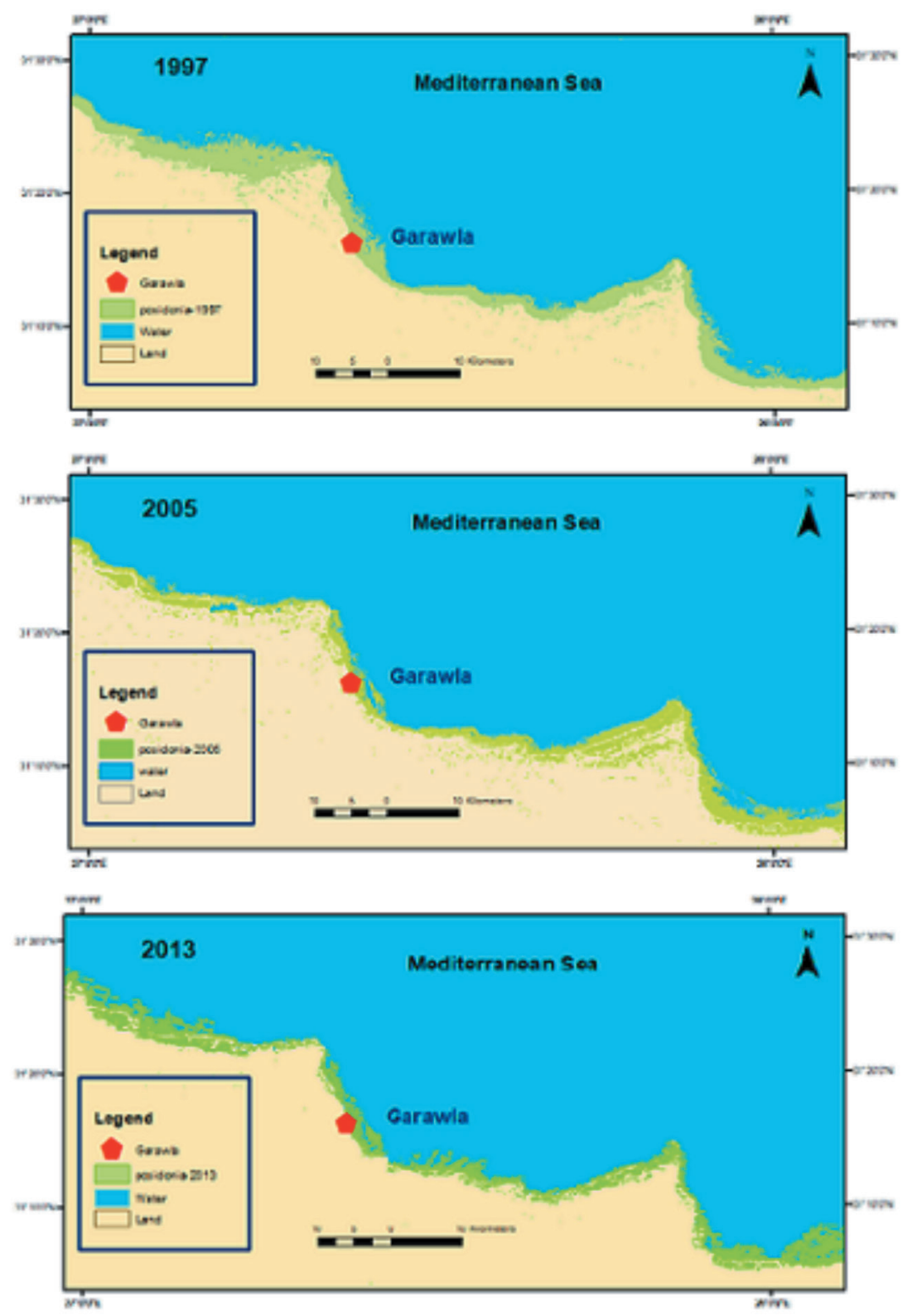

Figure 18. Distribution of coastal plant cover of the area under investigation during 1997, 2005 and 2013 years.

Human interference also considered as important factor (Marbà with his team and Boudouresque agreed that P.oceanica inhabited the Mediterranean Sea is experiencing a widespread decline (Marbà et al., 1996, Boudouresque, 2003). Marbà and Duarte suggested that this decline is due to different factors such as climate change (Marbà and Duarte, 1997). Different scientific researchers studied the reasons the deterioration of marine coastal environment and suggested that it may be due to anthropogenic pressure such as coastal development, pollution, some human activities (Roberts, 2000, Fyfe and Davis, 2007, Ruiz and Romero, 2003, Balestri et al., 2004). Also, its deterioration may be a result of transportation and accretion of sediment (Boudouresque et al., 1984), water temperature, hydrodynamic regime (La Loggia et al., 2004) and water transparency (Marbà and Duarte, 1997 and Guidetti, 2001). Most seagrass loss, both natural and anthropogenic, can be attributed to reduce light intensity; because of either turbidity 
and/or eutrophication, which promotes excessive epiphyte growth (Guidetti, 2001 and Short and Wyllie-Echeverria, 1996). Both processes effectively reduce the amount of light available for seagrass photosynthesis and exhaust its rhizomal starch (Touchette, and Burkholder, 2000 and McComb, et al., 1981).

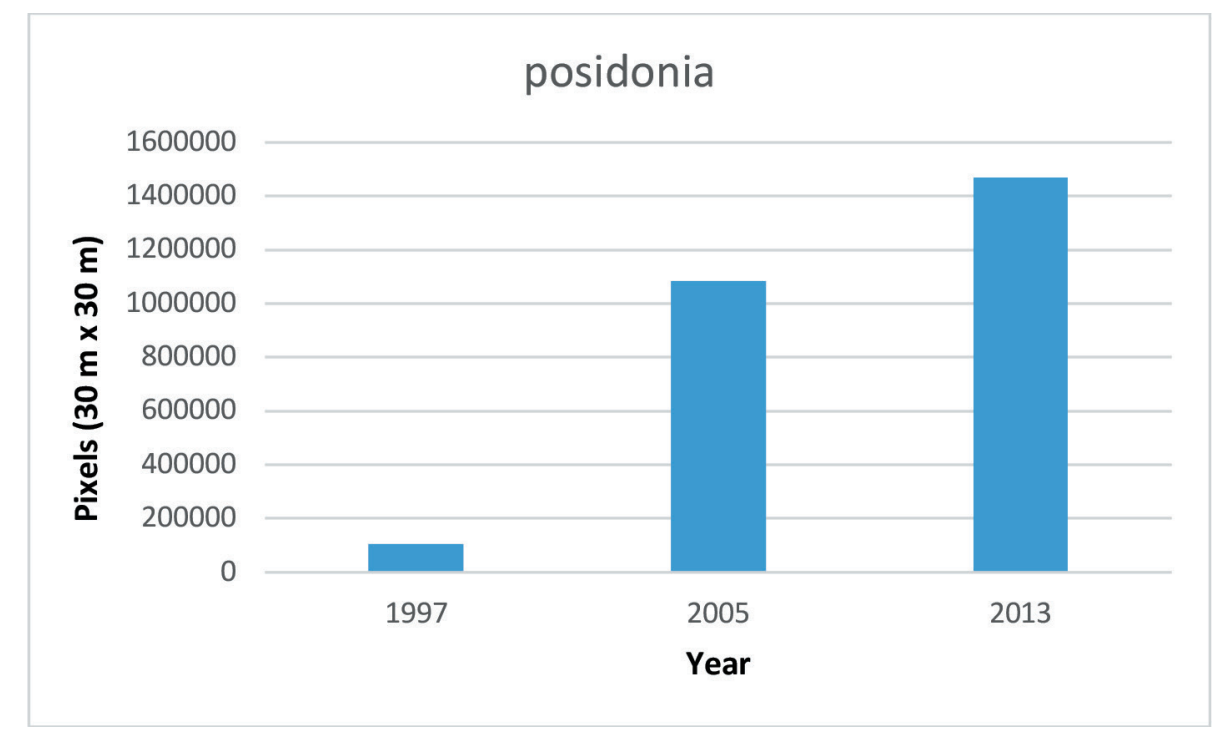

Figure 19. Counts of coastal plant cover of the area under investigation during 1997, 2005 and 2013 years.

\subsubsection{Advantages and Disadvantages of}

\section{Posidonia wrack}

Advantages of the Posidonia wrack concentrate of protect the beach from erosion and party of the scientists recommend to keep the wrack as it is to protect the shoreline from retreat. The way of keeping the wrack can be done in non-recreational areas. In recreational areas, Posidonia wrack acts as one of the environmental problems for the persons due to its odor, shape, mucous touch, inhabitation of zooplankton. Accumulated Posidonia is considered as natural resource. This resource can be used in different industries; to extract the cellulose and lignin, as food for animals, packing materials, as celling manufacture, and as internal materials of bellows. In addition, it can use as source of organic matter, shelter for marine organisms and animals, as bio- indicator for pollutions, and for fixation of the base of the coastal dunes. We proposed to use it as additive materials to manufacture a new break for building materials.

\section{Recommendations:}

1. The old stock of Posidonia wrack has to be harvested. Because this accumulated Posidonia act as source for the next points.

2. This study recommend to use net to prevent the transported dead Posidonia to park in the beach. These types of nets will be useful also to prevent the jelly fish to visit these beaches.

3. Study of tidal cycle for one year to know the exact duration.

4. Study of the surface and subsurface current for at least one year.

5. Establish Posidonia watch program to monitor 
this seagasses distribution.

6. Use of dispersion model to estimate the dispersion of these seagrasses.

7. The serious consequences on the $P$. oceanica seagrass meadows should be taken into considerationwhen a new hard coastal protection structure establish or make modifications to existing jetties or other structures.

8. It will be concluded that all possible consequences of such initiatives should be carefully considered before any action is taken.

\section{References:}

*Balestri, E., Benedetti-Cecchi, L., Lardicci, C., 2004. Variability in patterns of growth and morphology of Posidonia oceanica exposed to urban and industrial wastes: contrasts with two reference locations. J. Exp. Mar. Biol. Ecol. 308, $1-21$.

*Bell, A. (1983) Seaweed: stinking problem or natural asset? Ecos 35: 23-25..

*Bethoux, J., Cópin-Motegut, G., 1986. Biological fixation of atmospheric nitrogen in the Mediterranean Sea. Limnology and Oceanography, 31, 1353-1358.

*Bethoux, J.P., Copin-Montegut, G., 1986. Biological fixation of atmospheric nitrogen in the Mediterranean Sea. Limnology and Oceanography 31, 1353-1358.

*Boudouresque, C.F., 2003. The erosion of Mediterranean biodiversity. In: Rodriguez-Prieto, C., Pardini, G. (Eds.), The Mediterranean Sea: An Overview of its Present State and Plans for Future Protection. Servei de Publicacions de la Universitat de Girona, pp. 53-112.

*Boudouresque, C.F., Jeudy de Grissac, A., Meinesz,A., 1984. Relation entre la sèdimentation et l'allongement des rhizomes orthotropes de Posidonia oceanica dans la baie d'Elbu (Corse). In: Boudouresque, C.F., Jeudy de Grissac, A., Olivier, J. (Eds.), International Workshop on
Posidonia oceanica beds. GIS, Posidonie Publ., Marseille, pp. 185-191.

*Cardoso, P.G., Brandao, A., Pardal, M.A., Raffaelli, D., Marques, J.C., (2005). Resilience of Hydrobia ulvae populations to anthropogenic and natural disturbances. Marine Ecology Progress Series 289, 191-199.

*CEN (2005) Watching the Seagrass Grow a guide for community seagrass monitoring in NSW, Community Seagrass Monitoring Project, Community Environment Network, Reference Manual, Watching the seagrass grow, A guide for community seagrass monitoring in New South Wales, Community Environment Network (CEN).

*Cocco G. (2007) Bulding seawalls to sustain intertidal biodiversity in altered and urbanized estuaries, Building, Biodiversity, 3RD ISSUE: MARCH 2007

*Dive site directory (2006) Seagrass, Posidonia oceanica Seagrass Meadows under Threat.

*Fyfe, S.K. Davis A.R. (2007) Spatial scale and the detection of impacts on the seagrass Posidonia australis following pier construction in an embayment in southeastern Australia. Estuarine, Coastal and Shelf Science 74, 297-305 S.K. Fyfe, A.R. Davis

*Gómez-Pujol L., Orfila A., Álvarez-Ellacuría A., Terrados J., Tintoré J. (2013) Posidonia oceanica beach-cast litter in Mediterranean beaches: a coastal videomonitoring study. Journal of Coastal Research, Special Issue No. 65, pp 1768- 1773.

*Guidetti, P., 2001. Detecting environmental impacts on the Mediterranean seagrass Posidonia oceanica (L.) Delile: the use of reconstructive methods in combination with "beyond BACI" designs. J. Exp. Mar. Biol. Ecol. 260, 27-39.

*Hemminga, M.A., Duarte, C.M., 2000. Seagrass Ecology. Cambridge University Press, UK. 
*Kendrick, G. A., Kirkman, H. \& Burton, C. (1995) An Investigation Into Beach Cast Macro Algae and Marine Angiosperms. CSIRO Division of Fisheries Report. 64pp.

*Kennaecodiving (2007) Posidonia, Report of Posidonia oceanica survey 2006.

*La Loggia, G., Calvo, S., Ciraolo, G., Mazzola, A., Pirrotta, M., Sarà, G., Tomasello, A., Vizzini, S., 2004. Influence of hydrodynamic conditions on the production and fate of Posidonia oceanica in a semi-enclosed shallow basin (Stagnone di Marsala, western Sicily). Chem. Ecol. 20 (3), 183-201.

*Marbà, N., Duarte, C.M., 1997. Interannual changes in seagrass (Posidonia oceanica) growth and environmental change in the Spanish Mediterranean littoral zone. Limnol. Oceanogr. 42 (5), 800-810.

*Marbà, N., Duarte, C.M., Cebriàn, J., Gallegos, M.E., Olesen, B., Sand-Jansen, K., 1996. Growth and population dynamics of Posidonia oceanica on the Spanish Mediterranean coast: elucidating seagrass decline. Mar. Ecol. Prog. Ser. 137, 203 213.

*McComb, A.J., Cambridge, M.L., Kirkman, H., Kuo, J., 1981. The biology of Australian seagrasses. In: Pate, J.S., McComb, A.J. (Eds.), The Biology of Australian Plants. University of Western Australian Press, Nedlands, WA, pp. 258-293.

*Ochieng, C.A., Erftemeijer, P.L.A., 1999. Accumulation of seagrass beach cast along the Kenyan coast: a quantitative analysis. Aquatic Botany, 65, 221-238.

*Pasqualini, V., Pergent-Martini, C., Clabaut, P., Pergent, G., 1998. Mapping of Posidonia oceanica using aerial photographs and sidescan sonar: Application to the island of Corsica (France). Estuarine Coastal and Shelf Science, 47: 359-367.

*Pasqualini, V., Pergent-Martini, C., Clabaut,
P., Pergent, G., 1998. Mapping of Posidonia oceanica using aerial photographs and sidescan sonar: Application to the island of Corsica (France). Estuarine Coastal and Shelf Science, 47: 359-367.

*Pergent, G., 1992. Key species in the Mediterranean littoral. The importance of Posidonia oceanica meadows. The European coastline study. European Science Foundation and Commission of the European Communities, Galway, pp. 32-36.

*PIRSA (1999) Ecological Assessment of the South Australian Beach-cast Seagrass and Marine Algae Fishery Assessment Report Prepared for Environment Australia, against the Guidelines For The Ecologically Sustainable Management of Fisheries. For the purposes of Part 13(A) of the Environment Protection and Biodiversity Conservation Act 1999. November 2003 Primary Industries and Resources South Australia.

*PIRSA (2003) Ecological Assessment of the South Australian, Beach-cast Seagrass and Marine Algae Fishery, Assessment Report Prepared for Environment Australia, against the Guidelines For The Ecologically Sustainable Management Of Fisheries, For the purposes of Part 13(A) of the Environment Protection and Biodiversity Conservation Act 1999. Prepared by the Agriculture, Food and Fisheries Division of Primary Industries \& Resources, South Australia (PIRSA).

*Roberts D. E. (2000) Tuggerah Lakes Estuary Process Study, BIO-ANALYSIS: Marine, Estuarine \& Freshwater Ecology, Wyong Shire Council, Final Report, Management Status

*Ruiz, J.M., Romero, J., (2003) Effects of disturbances caused by coastal constructions on spatial structure, growth dynamics and photosynthesis of the seagrass Posidonia oceanica. Mar. Pollut. Bull. 46, 1523-1533.

*Short, F.T., Wyllie-Echeverria, S., 1996. Natural 
and human-induced disturbance of seagrasses. Environmental Conservation 23, 17-27.

*Touchette, B.W., Burkholder, J.M., 2000. Review of nitrogen and phosphorus metabolism in seagrasses. Journal of Experimental Marine Biology and Ecology 250, 133-167.

*Tsimplis, M. N., Zervakis, V., Josey, S. A., Peneva, E. L., Struglia, M. V., Stanev, E. V., Theocharis, A., Lionello, P., MalanotteRizzoli, P., Artale, V., Tragou, E., and Oguz, T.: (2006) Changes in the Oceanography of the Mediterranean Sea and their Link to Climate Variability, in: Mediterranean Climate Variability, edited by: Lionello, P., Malanotte-Rizzoli, P., Boscolo, R., Elsevier publishing, 227-282. 
